\title{
Evaluate the Use of Blog Sites in the Language Teaching and Learning
}

\author{
Rui Xu1 ${ }^{*}$, Qi Wang², Lili Zhou² \\ ${ }^{1}$ Anhui Vocational and Technical College, Hefei 230000, China \\ ${ }^{2}$ West Anhui Health Vocational College, Luan 237000, China \\ *Corresponding author: Rui Xu, 287986877@qq.com
}

\begin{abstract}
In the era of rapid development of information technology, an increasing number of educators involve blog sites in their language teaching process. Although blogs are incredibly effective in language teaching and learning, there is still space for growth. Students may be able to choose helpful learning content and share their thoughts with teachers and other language learners. Furthermore, as compared to traditional educational methods, blogs encourage students to communicate with their professors or other students in written form more frequently. As a result, it may help pupils enhance their reading and writing skills, as well as their learning initiative and vocabulary. Finally, it may allow students to track their learning progress, which may be beneficial in developing students' self-assessment, self-management, and self-education skills.
\end{abstract}

Keywords: Blog; Language teaching and learning; Learning autonomy; Language abilities

Publication date: December 2021; Online publication: December 27, 2021

There has been a growing interest in using blog sites in language teaching and learning in the educational area in the Web 3.0 era. A blog, according to Murray and Hourigan, is a type of personal online publishing that allows people to publicly express their thoughts while also allowing others to comment on them ${ }^{[1]}$. This essay argues that using blogs in the language teaching and learning process can benefit both teachers and students by allowing students to receive and share selected useful language learning information, creating a platform for teachers and students to communicate with one another, promoting students' learning autonomy and reading and writing proficiency, and improving their self-assessment, selfregulation, and self-regulation abilities. First, the essay will discuss how blogs may help teachers pick appropriate learning materials for students and allow language learners to exchange vital knowledge with one another. It will next be discussed how using blogs, rather of traditional teaching methods, may enable students to connect more with their teachers or other language learners, as well as boost learners' learning autonomy and interests, as well as their language reading and writing abilities. After that, it's time to look at how blogs can help students keep track of their learning and provide them opportunity to reflect on it, which may help them improve their self-assessment, self-management, and self-education skills. Finally, the article will look into the drawbacks of utilizing blogs in language learning and teaching.

Informational education is emerging and spreading all over the world in today's highly informationbased culture. Blogs are increasingly widely employed in the field of education, particularly in language teaching and learning. Every day, untold amounts of information are published in blogs online, and the quality of the content is variable. People may be concerned about deciding what to read and what to disregard. Language learners would be perplexed as to what material is worthwhile to read. Reading the meaningless material may potentially squander some of their study time. Since the introduction of blogs into the language instruction process, this type of event may be less common. Teachers should start by 
reading several language learning websites and blogs, then choose some high-quality content to include in their own blogs. They can include links to valuable language learning websites as well as video in their blogs for students to read and view. If teachers notice that there are some problems that students do not fully understand, they could add some articles, pictures or videos in their blogs to help students comprehend. In this case, teachers' blogs may accumulate a great deal of valuable language teaching and learning information. Language learners who do not have too much time could just pay attention to the teachers' blogs to choose the information they need which may greatly save their time. In addition, students could create their own blogs about language learning. They could add some useful information in their blogs and invite their teachers or classmates to read. Learners then may build habits to read other language learners' blogs and exchange and share useful information and ideas with each other. They could also get access to the latest language learning information by reading blogs. Noytim maintains that utilizing blogs in language teaching and learning would provide learners with opportunities to share useful language learning information with each other which may benefit learners' language learning ${ }^{[2]}$. Blackstone et al. ${ }^{[3]}$ also assert that using blogs might allow students to acquire useful language learning knowledge by reading teachers' and other classmates' blogs. Therefore, it could be concluded that using blogs in language teaching and learning process would help language learners select useful language learning information in short time and learn them by reading their teachers' and classmates' blogs.

In traditional teaching model, the most common way for teachers and students to interact with each other is face to face communication. In some language classes, students may be required to use the target language to communicate in the classroom. However, some students may not feel confident about their language proficiency especially their speaking abilities and consequently they are afraid to ask questions or express their opinions in class which would be harmful to their language learning. Blogs could set up a virtual platform for teachers and learners or learners and learners to communicate with each other. Students who are afraid to speak the target language would write their problems about language learning and express their ideas in their blogs. Teachers and other learners therefore could add their comments to answer the students' questions and exchange their opinions in the blogs. This process could be beneficial for teachers to find and think what are the difficulties in teaching and learning procedure, how to let students understand some key language points better and what are students really interested in and it may contribute to improving the teaching effect. Blogs used in language teaching could increase the interaction between teachers and students or learners and learners which would enhance students' language skills ${ }^{[4-6]}$. Moreover, students write their opinions in blogs which also practice their writing skills. Because blogs are open to the public, anyone could visit students' blogs and comment on their ideas. In many situations, the comments may stimulate students to reply and further reply the visitors which may finally create a small discussion. This kind of discussion may encourage learners to search more language knowledge, learn and use more new vocabularies and write blogs more actively. In this process, students keep writing blogs or replying comments because they would like to discuss with others and show their opinions which means that they write with purposes and write more freely. This could improve students learning interests and initiative, broaden students' language knowledge and vocabulary and improve their writing proficiency. This is confirmed by Amir et al. who claim that blogs would improve students' learning autonomy and writing abilities in language learning process ${ }^{[7]}$. Besides, Students also need to read visitors' comments and sometimes search and read other articles related to language to reply the questions visitors pointed out in their blog which could also practice students' language reading skills. A study conducted by Montero-Fleta and Pérez-Sabater also supports this point ${ }^{[8]}$. The study shows that students who frequently participate in blogs in language learning process acquire the higher level of language reading and writing abilities as well as language learning initiative than students in traditional teaching and learning form. Hence, it could be inferred that blogs would help to increase the communication between teachers and students or learners and 
learners which may improve the teaching result, promote students' learning autonomy as well as their abilities of language reading and writing and enlarge their vocabulary.

Students could also keep recording their language learning process in their blogs. They may write what articles they have read today, what language points they have not fully understand, what they have gained in class, what they have planned for their next language learning and even an idea just created in their brain. All these information they recorded would become a transcript of how they learn the language. Students could watch this record in their blogs and reflect their learning process. This process is like another "you" as an observer to review your learning process which may encourage students to rethink the way they thought and the problems they had at that time in their learning process. This kind of reflection could be beneficial for students to find the problems in their learning process and based on these problems students may learn how to solve the problems in their learning process, how to adjust and develop their own suitable and effective learning method and how to manage their study. Teachers and other learners could visit students' blogs and give their comments and suggestions which may also help students to solve their learning problems and plan their future language learning. Zhang argues that students documenting their language learning process in blogs would make it possible for them to reflect their learning procedure which would develop their abilities of self-assessment, self-management and self-education ${ }^{[9]}$. This means that students reviewing the way they thought and studied would help them discover the problems in their former language learning and this may allow them to learn how to assess their previous learning process. On basis of the assessment, students would gradually improve their learning method and understand how to manage their own study. Based on above, students may improve their abilities of critical thinking, self-assessment and self-management which might let students comprehend how to study and how to teach themselves. Thus, students may develop their abilities of self-assessment, self-management and self-education by utilizing blogs in language learning.

Even though there are several advantages to utilizing blogs in language teaching and learning as described above, there are some drawbacks. To begin with, most blogs just enable bloggers to input the words they want to communicate and visitors to view the material in the blogs. This type of form can only be used to improve language learners' reading and writing skills while ignoring their listening and speaking skills. Students who are reluctant to speak the target language may rely too heavily on blogs to convey their thoughts with professors and other students, rather than really opening their lips and speaking the target language. It would be counterproductive to improve kids' listening and speaking skills. According to a research conducted by Noytim, some students in this study say that blogs cause them to focus too much on reading and writing abilities after class and give little attention to listening and speaking skills ${ }^{[2]}$. Second, in comparison to the language used in school, the language used in blogs does not follow rigorous norms. When writing and responding to blogs, students frequently utilize colloquial language. They may write rapidly when they have a few words they want to communicate, which may result in some errors in their writing. They may develop habits as a result of their frequent blunders, resulting in a deterioration in their writing ability. Noytim supports this stance, stating that students writing blogs without error correction may degrade their writing abilities ${ }^{[2]}$. Finally, if students' blogs are accessible to the general public, anybody can remark on them. Visitors were also given the option of leaving anonymous remarks. In this case, some visitors who do not agree with the opinions which students published in the blogs may criticize the students directly. Consequently, students who are sensitive may gradually lose their interest in learning language. Blackstone et al. also claim that students' blogs exposed in public may receive some harsh comments which might hurt sensitive students' confidence of learning language ${ }^{[3]}$. Anyway, this problem may be solved if teachers create class blogs which do not open to the public. However, these three limitations of applying blogs in language learning would be relatively minor compared with the advantages of utilizing blogs in language learning. The benefits which using blogs in students' language learning could bring would 
overweigh the drawbacks to it. Teachers would pay more attention to students using the blogs in language learning and guide them to utilize the blogs to help them learning language more scientific and effective.

The blog, as shown above, is a wonderful instrument for language teaching and learning, despite some small drawbacks. Students may be able to access chosen valuable learning content and share their ideas with teachers and other language learners through blogs. Furthermore, it would encourage students to connect with their professors or other students via blogs rather than traditional teaching methods, which might improve students' reading and writing abilities, raise their learning initiative, and expand their vocabulary. Furthermore, it may allow students to document their learning experience, which may help them develop self-assessment, self-management, and self-education skills. Minor disadvantages of utilizing blogs in language teaching and learning include the inability to practice students' listening and speaking abilities, the disregard of students' writing correctness, and the reduction of some sensitive kids' learning interests. Teachers would plan better in teaching procedure and guide students more carefully to help them understand how to use blogs efficiently to improve their language proficiency.

\section{Funding}

(1) The Quality Project of West Anhui Health Vocational College in 2018, "Research on the Design and Application of Project-Based Blended Teaching of Nursing English in Vocational Colleges" (Number: YJZLGC201809, Project Director: Xin Li).

(2) The Provincial Quality Teaching and Research Project of Higher Education of Anhui Province in 2019, "Application and Research of Project-Based Teaching Method in Nursing English Courses in Medical Vocational Colleges" (Number: 2019jyxm0615, Project Director: Lili Zhou).

(3) The Key Project of Humanities and Social Science Research of Higher Education of Anhui Province in 2020, "Research on Employment-Oriented PBL System for Medical Students" (Number: SK2020A0721, Project Director: Lili Zhou).

\section{Disclosure statement}

The author declares that there is no conflict of interest.

\section{References}

[1] Murray L, Hourigan T, 2008, Blogs for Specific Purposes: Expressivist or Socio-cognitivist Approach? ReCall, 20(1): 82-97.

[2] Noytim U, 2010, Weblogs Enhancing EFL Students' English Language Learning. Procedia-Social and Behavioral Sciences, 2(2): 1127-1132.

[3] Blackstone B, Spiri J, Naganuma N, 2007, Pedagogical Uses and Student Responses. Reflection on English Language Teaching, 6(2): 1-20.

[4] Arslan RS, Sahin-Kizil A, 2010, How Can the Use of Blog Software Facilitate the Writing Process of English Language Learners? Computer Assisted Language Learning, 23(3): 183-197.

[5] Halic O, Lee D, Paulus T, Spence M, 2010, To Blog or Not to Blog: Student Perceptions of Blog Effectiveness for Learning in a College-Level Course. The Internet and Higher Education, 13(4): 206213.

[6] Mompean AR, 2010, The Development of Meaningful Interactions on a Blog Used for the Learning of English as a Foreign Language. Recall: The Journal of Eurocall, 22(3): 376. 
[7] Amir Z, Ismail K, Hussin S, 2011, Blogs in Language Learning: Maximizing Students' Collaborative Writing. Procedia-Social and Behavioral Sciences, 18(2): 537-543.

[8] Montero-Fleta B, Pérez-Sabater C, 2010, A Research on Blogging as a Platform to Enhance Language Skills. Procedia-Social and Behavioral Sciences, 2(2): 773-777.

[9] Zhang D, 2009, The Application of Blog in English Writing. Journal of Cambridge Studies, 4(1): 6472 . 